\title{
Hubungan Antara Kecerdasan Emosi dan Self Efficacy dalam Pemecahan Masalah Penyesuaian Diri Remaja Awal
}

\author{
Ni Made Wahyu Indrariyani Artha dan Supriyadi \\ Program Studi Psikologi, Fakultas Kedokteran, Universitas Udayana \\ wahyu.ia91@gmail.com
}

\begin{abstract}
Abstrak
Kehidupan remaja khususnya remaja awal tidak terlepas dari berbagai permasalahan karena perubahan secara fisik, kognitif dan sosio-emosional mempengaruhi kontrol diri dan pola pikir remaja terhadap lingkungan sekitar. Emosi dan keyakinan diri berperan penting dalam menghadapi berbagai permasalahan khususnya penyesuaian diri remaja. Berdasarkan hal tersebut penelitian ini bertujuan untuk mengetahui hubungan antara kecerdasan emosi dan self efficacy dalam pemecahan masalah penyesuaian diri remaja awal dan mengetahui sumbangan efektif kecerdasan emosi dan self efficacy dalam pemecahan masalah penyesuaian diri remaja awal.

Sampel penelitian ini adalah siswa kelas 1 SMA Negeri Denpasar sebanyak 129 orang dengan menggunakan teknik simple random sampling. Penelitian ini menggunakan tiga buah skala pengukuran, yaitu skala kecerdasan emosi, skala self efficacy, dan skala penyesuaian diri. Skala kecerdasan emosi terdiri dari 20 item dengan nilai reliabilitas $=0,822$; skala self efficacy terdiri dari 34 item dengan nilai reliabilitas $=0,913$; dan skala penyesuaian diri terdiri dari 31 item dengan nilai reliabilitas $=0,896$.

Berdasarkan hasil analisa regresi ganda diperoleh nilai koefisien korelasi $R=0,772, F$ regresi $=93,211, p=0,000$, yang berarti ada hubungan antara kecerdasan emosi dan self efficacy dalam pemecahan masalah penyesuaian diri remaja awal. Sumbangan efektif kecerdasan emosi dan self efficacy terhadap penyesuaian diri sebesar 59,70\%. Hasil analisis korelasi kecerdasan emosi dan self efficacy dengan penyesuaian diri masing-masing sebesar 0,632 dan 0,715 dengan $\mathrm{p}$ $=0,000$, yang berarti ada hubungan positif yang kuat antara kecerdasan emosi dan self efficacy dengan pemecahan masalah penyesuaian diri remaja awal.
\end{abstract}

Kata kunci: Kecerdasan emosi, self efficacy, dan pemecahan masalah penyesuaian diri

\begin{abstract}
Adolescence's life especially the early one cannot be separated from upcoming problems because their physical, cognitive, and socio-emotional changes are significantly affecting their self-controlling and mindset to their surrounding environment. Both of emotion and self-confidence are playing an important role on facing the problems especially on adolescent adjustment. The purposes of this research are to understand the relationship between emotional intelligence and self efficacy in problem solving of adjustment early adolescence and to understand effective contribution of emotional intelligence and self efficacy to problem solving of adjustment early adolescence.

The subjects in this research were 129 students of high school in Denpasar especially students in grade 10, who were chosen by simple random sampling. This research used three scales as measurement tools, namely emotional intelligence scale, self efficacy scale, and adjustment scale. Emotional intelligence scale has a reliability value $=0,822$, consist of 20 items; self efficacy scale has a reliability value $=0,913$, consist of 34 items; and adjustment scale has a reliability value $=0,896$, consist of 31 items

According to the result of multiple regression analysis, the value of $\mathrm{R}$ correlation $=0,772, \mathrm{~F}$ regression $=93,211, \mathrm{p}=$ 0,000 , there was relationship between emotional intelligence and self efficacy in problem solving of adjustment early adolescence. The effective contribution of emotional intelligence and self efficacy to adjustment are 59,70\%. The result of each correlation emotional intelligence and self efficacy to problem solving of adjustment early adolescence is 0,632 and 0,$715 ; p=0,000$, there was a positive and strength relationship between emotional intelligence and self efficacy in problem solving of adjustment early adolescence.
\end{abstract}

Keywords: emotional intelligence, self efficacy, and problem solving of adjustment 


\section{LATAR BELAKANG}

Kehidupan remaja tidak terlepas dari berbagai macam permasalahan yang ada dalam setiap tahap perkembangannya. Permasalahan yang ada tersebut dapat bersumber dari berbagai macam faktor seperti dari dalam diri sendiri, keluarga, teman sepergaulan atau lingkungan sosial. Masalah-masalah yang dihadapi memberikan suatu bentuk ujian bagi para remaja agar mampu menyesuaikan diri dengan lingkungan sekitar mereka. Hal ini dikarenakan oleh berbagai macam pertimbangan pada masa remaja sebagai periode transisi perkembangan antara masa kanak-kanak dengan masa dewasa, yang melibatkan perubahan biologis, kognitif, dan sosio-emosional (Santrock, 2007). Menurut periode perkembangan manusia, masa remaja merupakan periode yang akan dilalui sebelum memasuki periode masa dewasa. Dalam masa remaja, individu memasuki tahapan masa remaja awal terlebih dahulu. Masa remaja awal menurut Hurlock (1994) berada pada rentang usia 13 hingga 16 atau 17 tahun, sedangkan Monks (2006) menyatakan bahwa masa remaja awal berusia 12-15 tahun. Pada masa ini kontrol terhadap dirinya bertambah sulit dan mereka cepat marah dengan caracara yang kurang wajar untuk meyakinkan dunia sekitarnya (Ali \& Asrori, 2011). Cara-cara yang kurang wajar tersebut dapat terjadi seperti misalnya perilaku yang lebih agresif, memberontak, menunjukkan kemarahan dengan emosi yang meledak-ledak (Ali \& Asrori, 2011).

Selain kontrol diri yang sulit, pada masa remaja awal pola pemikirannya pun mulai berkembang dan pengetahuan yang diperoleh dari lingkungan sekitar mulai bertambah. Adapun perubahan kognitif yang terjadi berdasarkan teori kognitif Piaget (dalam Santrock, 2007), terletak pada tahap pemikiran operasi formal atau formal operational. Menurut Piaget, remaja tidak lagi terbatas pada pengalamanpengalaman yang aktual dan konkret sebagai titik tolak pemikirannya. Pada tahap ini ditandai oleh pemikiran yang abstrak, idealistik, dan logis. Remaja mulai berpikir seperti ilmuwan, membuat rencana untuk memecahkan masalah dan secara sistematis menguji solusi. Tipe pemecahan masalah yang dilakukan oleh remaja tersebut dinamakan oleh Piaget (dalam Santrock, 2007) sebagai penalaran hipotesis deduktif, yang berarti kemampuan untuk mengembangkan sebuah hipotesis atau dugaan, mengenai bagaimana memecahkan masalah, seperti menyelesaikan perhitungan aljabar yang setelah itu secara sistematis melakukan deduksi terhadap langkah terbaik yang harus diikuti untuk memecahkan masalah. Menurut Reed (dalam Sternberg, 2009), pemecahan masalah merupakan suatu upaya untuk mengatasi rintangan yang menghambat suatu solusi. Pada tahap remaja awal, upaya dalam mencapai suatu solusi untuk memecahkan masalah dapat dikatakan mengalami banyak rintangan. Menurut Stanley Hall (dalam Santrock, 2007), masa remaja dipandang sebagai masa "storm and stress", remaja mengalami pergolakan yang dipenuhi oleh konflik dan perubahan suasana hati. Berbagai pikiran, perasaan, dan tindakan remaja berubahrubah antara kesombongan dan kerendahan hati, niat yang baik dan godaan, kebahagiaan dan kesedihan. Berdasarkan hal tersebut remaja menjadi bingung untuk memutuskan setiap tindakan yang akan diambilnya. Hal ini disebabkan oleh adanya faktor eksternal dari luar diri remaja yaitu remaja harus siap dan mampu menyesuaikan diri dengan lingkungan di samping faktor internal yang terjadi pada remaja yaitu perubahan biologis, kognitif, dan sosio-emosional.

Menyelaraskan antara kondisi yang terjadi dalam diri sendiri dan lingkungan sekitar merupakan sikap dalam menyesuaikan diri. Kehidupan remaja tidak lagi hanya sebatas pada keluarga melainkan pengaruh dari lingkungan sekolah, teman dalam kelompok dan masyarakat memegang peranan penting dalam penyesuaian diri remaja. Menurut Atwater (1983) penyesuaian diri terdiri dari perubahan dalam diri dan lingkungan sekitar untuk mencapai suatu hubungan yang memuaskan dengan orang lain dan lingkungan sekitar. Menurut Runyon dan Haber (1984), penyesuaian diri sebagai keadaan atau sebagai proses yang terus berlangsung dalam kehidupan individu. Penyesuaian diri sebagai proses menunjukkan bagaimana penyesuaian diri yang efektif dapat diukur dengan mengetahui bagaimana kemampuan individu menghadapi perubahan di lingkungannya. Runyon dan Haber (1984), menyebutkan bahwa penyesuaian diri yang dilakukan individu memiliki lima aspek sebagai berikut: a) persepsi terhadap realitas, individu mengubah persepsinya tentang kenyataan hidup dan menginterpretasikan suatu kejadian, sehingga mampu menentukan tujuan yang realistic, b) kemampuan mengatasi stres dan kecemasan, mengatasi masalah-masalah dalam hidup dan menerima kegagalan yang dialami, c) gambaran diri yang positif, individu mempunyai gambaran diri yang positif baik melalui penilaian pribadi maupun melalui penilaian orang lain, sehingga individu dapat merasakan kenyamanan psikologis, d) kemampuan mengekspresikan emosi dengan baik, individu memiliki ekspresi emosi dan kontrol emosi yang baik, dan e) hubungan interpersonal yang baik, mampu membentuk hubungan dengan cara yang berkualitas dan bermanfaat satu sama lain.

Dalam menghadapi perubahan yang terjadi dalam diri dan lingkungan di sekitar, remaja harus mampu untuk menyesuaikan diri terhadap perubahan tersebut. Karakteristik penyesuaian diri yang terjadi pada remaja dapat terlihat dari penyesuaian diri terhadap peran dan identitas, pendidikan, kehidupan seks, norma sosial, penggunaan waktu luang, penggunaan uang atau finansial serta penyesuaian diri terhadap kecemasan, konflik, dan frustrasi (Ali \& Asrori, 2011). Tentu saja dalam proses penyesuaian diri tersebut, remaja tidak terlepas dari berbagai macam masalah sehingga memerlukan suatu solusi atau pemecahan masalah agar penyesuaian diri tercapai dengan baik. 
Dalam penyesuaian diri terhadap peran dan identitas, remaja memainkan perannya sebagai subjek yang memiliki kepribadian yang berbeda dibandingkan ketika berada dalam masa anak-anak. Hal ini dilakukan agar mampu memperoleh identitas diri yang semakin jelas sebagai remaja dan diterima oleh lingkungan di sekitarnya. Masalah terkait dengan penyesuaian diri remaja dapat terjadi ketika remaja tersebut menjalankan antara kegiatan belajar dan kegiatan dengan teman-temannya. Di salah satu sisi remaja ingin menyelesaikan tugas atau pekerjaan sekolah, di sisi lain adanya pengaruh dari teman yang mengajak untuk melakukan kegiatan-kegiatan di luar kegiatan belajar seperti bermain. Hal ini dapat menjadi konflik dalam diri remaja itu sendiri yaitu apakah harus membiarkan tugas-tugasnya atau mencari pengalaman baru bersama teman-temannya.

Selain itu juga, keadaan finansial yang ada pada remaja dapat mempengaruhi dalam melakukan penyesuaian diri karena remaja belum sepenuhnya mandiri dan dalam masalah finansial masih bergantung pada orang tuanya (Ali \& Asrori, 2011). Rangsangan, tantangan, tawaran, dan kesempatan-kesempatan yang ada di sekitar diri remaja mengakibatkan melonjaknya penggunaan uang pada remaja sehingga menyebabkan jatah yang diterima dari orang tua tidak cukup (Ali \& Asrori, 2011). Kemampuan remaja dalam menyesuaikan diri terhadap keadaan finansial orang tua dan pengaruh dari lingkungan sekitar dapat dicontohkan melalui perkembangan teknologi dan informasi saat ini. Menurut Hastuti, perkembangan teknologi canggih seperti ponsel, laptop, ataupun notebook menarik perhatian remaja untuk berlomba-lomba dalam memiliki benda-benda tersebut (dalam harianjoglosemar.com, 14 Maret 2010). Dengan munculnya berbagai macam media elektronik tersebut, dapat menimbulkan rasa keinginan dalam diri remaja untuk memilikinya akan tetapi remaja juga harus melihat bagaimana kondisi finansial yang ada. Untuk menghadapi hal itu, remaja harus mampu dalam menemukan jalan keluar agar dapat menyesuaikan diri terhadap kondisi finansial orang tua mereka dengan keadaan atau perubahan yang terjadi di lingkungan sekitar.

Selain itu, permasalahan yang kerap kali terjadi pada remaja adalah masalah terkait dengan emosi yang labil dan kemampuan berpikir dalam menemukan solusi yang tepat dalam menghadapi suatu masalah. Ketika remaja mengalami suatu masalah, terjadi kebingungan dalam diri yang mengarahkan pada ketidakmampuan dalam menyesuaikan diri secara tepat terhadap kenyataan yang ada. Sehingga banyak kasus yang terjadi pada remaja saat ini adalah ketidakmampuan dalam menemukan solusi yang tepat terhadap masalah yang dihadapi sehingga mengambil jalan yang keliru seperti bunuh diri atau melampiaskannya dengan menggunakan obat-obatan terlarang. Menurut data Komnas Perlindungan Anak (dalam Suara Karya Online, 24 Juli
2012), dari awal hingga tengah tahun 2012 terdapat 20 kasus bunuh diri pada anak dengan rentang usia 13-17 tahun, sebanyak delapan kasus bunuh diri dilatari masalah cinta, tujuh kasus akibat ekonomi, empat kasus masalah disharmoni keluarga, dan satu kasus masalah sekolah. Di samping itu juga berdasarkan data World Health Organization (WHO), pada tahun 2005 tercatat 50 ribu penduduk Indonesia bunuh diri setiap tahun. Dari kejadian kasus bunuh diri tersebut, ternyata kasus yang paling tinggi terjadi pada rentang usia remaja hingga dewasa muda, yakni 15-24 tahun, fakta ini berhubungan dengan peningkatan tajam angka depresi pada remaja (dalam Pontianak Post, 25 September 2012). Sedangkan dari data Badan Narkotika Nasional (dalam Republika Online, 23 Mei 2012), kasus penyalahgunaan narkoba terus meningkat di kalangan remaja dari $2,21 \%$ (4 juta orang) pada tahun 2010 menjadi 2,8\% (sekitar 5 juta orang) pada tahun 2011.

Terlepas dari kasus bunuh diri dan penggunaan obatobatan terlarang, ada hal lain yang dapat ditunjukkan terhadap bentuk perilaku pada perkembangan diri remaja. Menurut Otto Rank (dalam Sarwono, 2011), pada remaja terjadi suatu perubahan drastis dari will, yaitu dari keadaan tergantung kepada orang lain (dependence) pada masa anak-anak menuju kepada keadaan mandiri (independence) pada masa dewasa. Berdasarkan pernyataan tersebut dapat diketahui bahwa remaja lebih memilih untuk mandiri terhadap keputusan yang akan diambil meskipun terkadang remaja mengalami kesulitan dan kebingungan terhadap keputusan yang diambil. Kemandirian remaja dalam memutuskan setiap tindakan yang diambil ataupun menentukan solusi atas permasalahannnya melibatkan kemampuan berpikir mereka apakah sanggup untuk melaksanakannya secara mandiri atau tidak. Untuk menghadapi permasalahan yang ada, seorang remaja harus memiliki suatu kemampuan dalam diri atau keyakinan diri agar dapat menemukan jalan keluar terhadap permasalahannya tersebut.

Dalam menemukan jalan keluar terhadap permasalahannya menurut teori sosial kognitif Bandura (1999) dibutuhkan peranan dari fungsi kognitif yang mana menyangkut self efficacy. Bandura (dalam Feist \& Feist, 2009) menyatakan bahwa keyakinan seseorang terhadap kemampuan yang dimiliki untuk mengontrol fungsi diri dan lingkungannya dinamakan self efficacy. Selain itu juga, self efficacy merupakan faktor dari perubahan kognitif pada remaja yang menurut Bandura (1994) sendiri yaitu kemampuan seseorang untuk menampilkan tindakan-tindakan dari level yang ditunjukkan. Self efficacy menentukan bagaimana orang-orang merasakan, berpikir, memotivasi dirinya dan berperilaku. Seorang remaja dalam memecahkan masalah dalam proses penyesuaian diri memerlukan suatu keyakinan terhadap kemampuan diri sendiri karena hal tersebut akan menentukan tindakan yang dilakukan dan hasil yang ditunjukkan. Bandura 
(1994) menyatakan bahwa individu yang memiliki keyakinan tinggi terhadap kemampuan yang dimiliki ketika menghadapi tugas-tugas yang sulit akan menganggap hal tersebut sebagai tantangan yang harus dikuasai, mempertahankan komitmen diri dalam mencapai tujuan, memperoleh kembali upayaupaya ketika menghadapi kegagalan, ketika menghadapi situasi yang mengancam mampu mengontrol dirinya, sehingga dapat menghasilkan pencapaian diri serta dapat mengurangi stress dan tidak mudah depresi. Sedangkan individu yang meragukan kemampuan dirinya akan menganggap tugas-tugas tersebut sebagai ancaman, memiliki harapan yang rendah, memiliki komitmen yang rendah terhadap tujuan yang dicapai, cepat menyerah dan kurang berusaha ketika menghadapi tugas yang sulit, serta lambat untuk bangkit kembali setelah mengalami kegagalan sehingga individu tersebut mudah mengalami stress dan depresi.

Menurut Bandura (dalam Anwar, 2009), terdapat tiga aspek dari self efficacy yang terdiri dari: 1) tingkatan (level), perbedaan self efficacy dari masing-masing individu dalam menghadapi suatu tugas dikarenakan perbedaan tuntutan yang dihadapi, jika halangan dalam mencapai tuntutan tersebut sedikit maka aktivitas mudah dilakukan, 2) keadaan umum (generality), individu akan menilai diri merasa yakin melalui bermacam-macam aktivitas atau hanya dalam daerah fungsi tertentu, 3) kekuatan (strength), pengalaman memiliki pengaruh terhadap self efficacy yang diyakini seseorang, pengalaman yang lemah akan melemahkan keyakinannya pula sedangkan keyakinan yang kuat terhadap kemampuan akan teguh dalam berusaha.

Menumbuhkan self efficacy pada remaja tidak terlepas dari bagaimana kemampuan yang ada dalam diri remaja tersebut yang melibatkan perasaan dan emosi di samping intelektual yang dimiliki. Perubahan pada diri remaja tidak semata-mata hanya pada fisik dan kognitif saja sebab setiap manusia memiliki emosi untuk mengekspresikan setiap perilaku mereka terhadap lingkungan sekitar. Hal ini terkait juga dengan bagaimana kecerdasan emosi ikut berperan dalam membentuk keyakinan diri pada remaja dalam memutuskan setiap tindakan yang akan diambil. Kecerdasan merupakan kemampuan menghadapi dan menyesuaikan diri terhadap situasi baru secara cepat dan efektif (Yusuf, 2011). Jean Piaget (dalam Ali \& Asrori, 2011) menyatakan bahwa kecerdasan yaitu seluruh kemampuan berpikir dan bertindak secara adaptif, termasuk kemampuan mental yang kompleks seperti berpikir, mempertimbangkan, menganalisis, mensintesis, mengevaluasi, dan menyelesaikan persoalan-persoalan. Emosi menurut English dan English (dalam Yusuf, 2011), merupakan suatu keadaan perasaan yang kompleks yang disertai karakteristik kegiatan kelenjar dan motoris. Sedangkan menurut Goleman (2009), emosi merujuk kepada suatu perasaan dan pikiran-pikiran yang khas, suatu keadaan biologis dan psikologis, dan serangkaian kecenderungan untuk bertindak.

Keberhasilan atau kegagalan seseorang dalam mengelola emosinya oleh Goleman (dalam Sarwono, 2011) dikatakan tergantung pada kecerdasan emosi. Makin tinggi kecerdasan emosi seseorang, makin bisa individu mengatasi berbagai masalah, khususnya yang memerlukan kendali emosi yang kuat. Menurut Goleman (2009), kecerdasan emosional yaitu kemampuan untuk memotivasi diri sendiri dan bertahan menghadapi frustrasi, mengendalikan dorongan hati dan tidak melebih-lebihkan kesenangan, mengatur suasana hati dan menjaga agar beban stress tidak melumpuhkan kemampuan berpikir, berempati dan berdoa. Menurut Goleman (2009), kecerdasan emosi terdiri dari lima aspek atau komponen utama yaitu : 1) mengenali emosi diri, suatu kemampuan untuk mengenali perasaan sewaktu perasaan itu terjadi, 2) mengelola emosi, kemampuan individu dalam menangani perasaan agar dapat terungkap dengan tepat atau selaras, sehingga tercapai keseimbangan dalam diri individu, 3) memotivasi diri, kemampuan untuk bertahan dan terus menerus berusaha menemukan banyak cara demi mencapai tujuan, 4) mengenali emosi orang lain, kemampuan seseorang untuk mengenali orang lain atau peduli, menunjukkan kemampuan empati seseorang, peka terhadap perasaan orang lain dan lebih mampu untuk mendengarkan orang lain, 5) membina hubungan dengan orang lain, individu mampu menangani emosi orang lain. Untuk mengatasi emosi orang lain dibutuhkan dua keterampilan emosi yaitu manajemen diri dan empati. Dengan landasan ini, keterampilan berhubungan dengan orang lain akan menjadi matang dan memungkinkan seseorang membentuk suatu hubungan untuk menggerakkan orang lain, membina kedekatan hubungan, meyakinkan, mempengaruhi dan membuat orang lain merasa nyaman.

Berdasarkan pendapat yang dikatakan oleh Goleman (dalam Martin, 2011), 20\% kesuksesan ditentukan oleh IQ, tetapi $80 \%$ kesuksesan ditentukan oleh faktor EQ. Beliau menyampaikan bahwa dua jenis pikiran kita, yakni yang rasional dan emosional, bekerja sama membentuk masa depan dan kesuksesan kita. Selain pendapat yang disampaikan oleh Goleman, Reuven Bar-On (2006) menyatakan bahwa kecerdasan emosional adalah kemampuan, kompetensi emosional dan sosial yang mempengaruhi kemampuan seseorang untuk memahami diri sendiri dan orang lain serta berhasil dalam mengatasi tuntutan, tantangan dan tekanan sehari-hari. Bar-On juga menyampaikan bahwa orang yang cerdas secara emosi cenderung untuk lebih optimis, fleksibel, lebih realistis, dan mampu mengatasi masalah serta menghadapi tekanan. Berdasarkan hal-hal tersebut dapat dipertimbangkan bahwa seorang remaja yang dikatakan memiliki kecerdasan intelektual yang tinggi belum tentu memiliki kecerdasan emosional yang tinggi. Sebab kecerdasan emosi berkaitan dengan bagaimana remaja tersebut mampu 
untuk mengelola emosi dalam melakukan setiap pekerjaan atau menghadapi segala macam bentuk masalah. Goleman (dalam Martin, 2011) juga menunjukkan lebih jauh bagaimana 'otak yang emosional' (EQ) ternyata lebih berperan daripada 'otak yang rasional' (IQ), khusunya dalam hal hubungan kerja, kesehatan, dan juga pencapaian akademis.

Apabila ditelaah lagi, perilaku atau tindakan yang dimunculkan oleh masing-masing individu tergantung dari emosi dan pikiran yang muncul sebelum mereka memutuskan untuk bertindak. Kemunculan emosi dari dalam diri remaja awal yang terbilang masih belum stabil memungkinkan keterkaitannya dengan keyakinan yang dimiliki dalam menghadapi setiap permasalahan. Sebab, setiap emosi yang dialami oleh remaja akan berdampak terhadap perilaku nyata yang dimunculkan. Keyakinan dalam diri remaja akan kemampuan yang dimiliki dapat menentukan tindakan apa yang akan dilakukan dalam mencapai suatu tujuan seperti menemukan jalan keluar terhadap masalah yang dihadapi sehingga dapat tercapai kesesuaian dalam diri remaja dan perubahan yang terjadi lingkungan di sekitar. Oleh karena itu, berdasarkan latar belakang di atas tujuan dari penelitian ini adalah untuk mengetahui hubungan antara kecerdasan emosi dan self dalam pemecahan masalah penyesuaian diri remaja awal, mengetahui hubungan antara kecerdasan emosi dengan pemecahan masalah penyesuaian diri remaja awal, mengetahui hubungan antara self efficacy dengan pemecahan masalah penyesuaian diri remaja awal, dan mengetahui sumbangan efektif kecerdasan emosi dan self efficacy dalam pemecahan masalah penyesuaian diri remaja awal.

\section{METODE}

\section{Variabel dan definisi operasional}

Dalam penelitian ini variabel bebasnya adalah kecerdasan emosi dan self efficacy dan variabel tergantungnya adalah pemecahan masalah penyesuaian diri.

Definisi operasional dari kecerdasan emosi yaitu dasar-dasar pembentukan emosi yang mencakup keterampilanketerampilan atau kemampuan dalam emosional dan sosial yang kemudian membentuk watak dan karakteristik yang didalamnya terkandung kemampuan-kemampuan merasakan emosi, memahami emosi, menerima dan membangun emosi dengan baik, memotivasi diri sendiri, semangat, kesabaran, dan kemampuan menjalin hubungan dengan orang lain atau empati, yang mana dengan keterampilan-keterampilan tersebut mampu mengendalikan impuls-impuls dan menyalurkan emosi yang kuat secara efektif. Kecerdasan emosi ini akan diungkap melalui skala kecerdasan emosi dengan berdasarkan pada aspek-aspek kecerdasan emosi yang dikemukakan oleh Goleman, yaitu mengenali emosi diri, mengelola emosi, memotivasi diri, mengenali emosi orang lain, dan membina hubungan dengan orang lain.
Definisi operasional dari self efficacy yaitu keyakinan individu dengan kemampuan yang dimilikinya dalam mengorganisasi diri untuk melaksanakan dan menyelesaikan suatu tugas yang dihadapi untuk mencapai tujuan tertentu. Diukur menggunakan skala self efficacy yang disusun berdasarkan aspek-aspek self efficacy yang dikemukakan oleh Bandura yaitu tingkat (level), keadaan umum (generality), dan kekuatan (strength).

Definisi dari operasional penyesuaian diri yaitu proses yang dialami oleh individu dalam mengatasi atau menguasai kebutuhan dalam diri, ketegangan, frustasi, dan konflik dengan tujuan untuk mendapatkan kesesuaian, keharmonisan dan keselarasan antara tuntutan lingkungan sekitarnya dengan tuntutan dalam dirinya. Diukur menggunakan skala penyesuaian diri yang disusun berdasarkan aspek-aspek penyesuaian diri yang dikemukakan oleh Runyon dan Haber yang terdiri dari persepsi terhadap realitas, kemampuan mengatasi stres dan kecemasan, gambaran diri yang positif, kemampuan mengekspresikan emosi dengan baik, dan hubungan interpersonal yang baik.

\section{Responden}

Dalam penelitian ini populasi yang akan digunakan adalah remaja awal dengan rentang usia 13-16 tahun (Hurlock, 1994) yang tertuju pada seluruh siswa kelas 1 SMA di SMA Negeri Denpasar. Teknik pengambilan sampel dalam penelitian ini menggunakan teknik simple random sampling. Melalui teknik ini, SMA Negeri di Denpasar yang menjadi tujuan penelitian di pilih secara acak dan juga pemilihan dua kelas dari masing-masing sekolah yang terpilih akan diacak. Untuk pengambilan sampel dari kelas yang terpilih akan dilakukan teknik propotionate random sampling untuk mengetahui probabilitas jumlah siswa yang dipilih dari masing-masing kelas. Jumlah sampel dalam penelitian ini sebanyak 129 siswa yang terdiri dari SMAN 2 sejumlah 47 siswa, SMAN 5 sejumlah 34 siswa dan SMAN 8 sejumlah 48 siswa.

\section{Tempat Penelitian}

Untuk pengambilan data try out dilakukan di SMAN 7 Denpasar, sedangkan pengambilan data setelah try out dilakukan di SMAN 2, SMAN 5, dan SMAN 8 Denpasar.

\section{Alat ukur}

Alat ukur dalam penelitian ini menggunakan tiga buah skala yaitu skala kecerdasan emosi, self efficacy, dan penyesuaian diri. Skala kecerdasan emosi yang berdasar pada 5 aspek yang dikemukakan oleh Goleman yaitu mengenali emosi diri, mengelola emosi, memotivasi diri, mengenali emosi orang lain, dan membina hubungan dengan orang lain, 
dengan jumlah aitem sebanyak 50 ; skala self efficacy yang berdasar pada 3 aspek yang dikemukakan oleh Bandura yaitu level, generality, dan strength dengan jumlah aitem sebanyak 60; dan skala penyesuaian diri yang berdasar pada 5 aspek yang dikemukakan oleh Bandura yaitu persepsi terhadap realitas, kemampuan mengatasi stres dan kecemasan, gambaran diri yang positif, kemampuan mengekspresikan emosi dengan baik, dan hubungan interpersonal yang baik, dengan jumlah aitem sebanyak 50.

\section{Teknik pengumpulan data}

Metode pengumpulan data dalam penelitian ini adalah dengan menggunakan kuesioner tertutup. Dalam penelitian ini peneliti memberikan kuesioner yang disusun dengan menyediakan pilihan jawaban, sehingga responden hanya memberikan tanda pada jawaban yang dipilih. Dalam penelitian ini peneliti menggunakan tiga kuesioner yaitu kuesioner pengukuran kecerdasan emosi, kuesioner pengukuran self efficacy, dan kuesioner penyesuaian diri. Pengumpulan data dalam penelitian ini dilaksanakan pada tanggal 5 - 8 Desember 2012 di SMAN 2, SMAN 5, dan SMAN Denpasar. Setelah data terkumpul, peneliti melakukan skoring untuk keperluan analisis data.

\section{Teknik Analisis Data}

Teknik analisis data yang digunakan dalam penelitian ini adalah analisis regresi ganda. Analisis ini meramalkan bagaimana keadaan (naik turunnya) variabel dependen (kriterium), bila dua atau lebih variabel independen sebagai faktor prediktor dimanipulasi (dinaik turunkan nilainya) (Sugiyono, 2012). Dalam penelitian ini analisis regresi ganda digunakan untuk mengetahui hubungan dua variabel bebas yaitu kecerdasan emosi dan self efficacy terhadap variabel terikat yaitu penyesuaian diri. Analisis data dalam penelitian ini menggunakan program SPSS windows versi 17

\section{HASIL PENELITIAN}

Berdasarkan hasil uji validitas dan reliabilitas yang dilakukan, untuk skala kecerdasan emosi terdapat 20 aitem yang valid dan 30 aitem yang gugur dengan rentang koefisien validitas dari 0,267 sampai 0,593 dan koefisien reliabilitas sebesar 0,822 pada aitem yang valid. Skala self efficacy didapatkan 34 aitem yang valid dan 26 aitem yang gugur dengan rentang koefisien validitas dari 0,274 sampai 0,672 dan koefisien reliabilitas sebesar 0,913. Sedangkan, skala penyesuaian diri didapatkan 31 aitem yang valid dan 19 aitem yang gugur dengan koefisien validitas dari 0,265 sampai 0,710 dan koefisien reliabilitas sebesar 0,896 .

Dari hasil analisis data diperoleh bahwa ketiga variabel dalam penelitian ini berdistribusi normal. Nilai Asymp.Sig (2-tailed) dari data kecerdasan emosi sebesar
0,551; nilai Asymp.Sig (2-tailed) dari data self efficacy sebesar 0,592 ; dan nilai Asymp.Sig (2-tailed) dari data penyesuaian diri sebesar 0,651. Nilai signifikansi dari ketiga variabel tersebut menunjukkan lebih dari 0,05 maka dapat disimpulkan bahwa variabel kecerdasan emosi, self efficacy, dan penyesuaian diri berdistribusi normal. Untuk hasil selengkapnya dapat dilihat pada tabel di bawah ini :

One-Sample Kolmogorov-Smirnov Test

\begin{tabular}{|c|c|c|c|c|}
\hline & & $\begin{array}{c}\text { Total } \\
\text { Kecerdasan } \\
\text { Emosi }\end{array}$ & $\begin{array}{l}\text { Total Self } \\
\text { Efficacy }\end{array}$ & $\begin{array}{c}\text { Total } \\
\text { Penyesuaian } \\
\text { Diri } \\
\end{array}$ \\
\hline \multirow{3}{*}{ Normal Parameters ${ }^{\mathrm{a}, \mathrm{b}}$} & $\mathrm{N}$ & 129 & 129 & 129 \\
\hline & Mean & 56.36 & 101.72 & 90.12 \\
\hline & Std. Deviation & 6.176 & 10.549 & 9.656 \\
\hline \multirow{5}{*}{$\begin{array}{l}\text { Most Extreme } \\
\text { Differences }\end{array}$} & Absolute & .070 & .068 & .065 \\
\hline & Positive & .041 & .068 & .065 \\
\hline & Negative & -.070 & -.038 & -.033 \\
\hline & $\begin{array}{l}\text { Kolmogorov- } \\
\text { Smirnov Z }\end{array}$ & .796 & .771 & .736 \\
\hline & $\begin{array}{l}\text { Asymp. Sig. (2- } \\
\text { tailed) }\end{array}$ & .551 & .592 & .651 \\
\hline
\end{tabular}

Selain itu juga berdasarkan uji multikolinearitas menunjukkan bahwa pada model regresi tidak terjadi masalah multikolinearitas atau tidak adanya hubungan yang liniear antara kedua variabel bebas tersebut dengan nilai tolerance dari variabel kecerdasan emosi dan self efficacy sebesar 0,710. Sedangkan, nilai VIF dari variabel kecerdasan emosi dan self efficacy sebesar 1,408. Untuk hasil selengkapnya dapat dilihat pada tabel di bawah ini :

Hasil Uji Multikolonieritas pada Tabel Coefficients (Collinearity Statistics)

\begin{tabular}{|c|c|c|}
\hline \multirow[b]{2}{*}{ Model } & \multicolumn{2}{|c|}{ Collinearity Statistics } \\
\hline & Tolerance & VIF \\
\hline 1 Total Kecerdasan Emosi & .710 & 1.408 \\
\hline Total Self Efficacy & .710 & 1.408 \\
\hline
\end{tabular}

a. Dependent Variable: Total Penyesuaian Diri

Untuk menguji apakah terdapat ketidaksamaan varian dari residual pada model regresi dilakukan uji heteroskedastisitas. Hasil dari uji heteroskedastisitas dapat dilihat pada gambar di bawah ini :

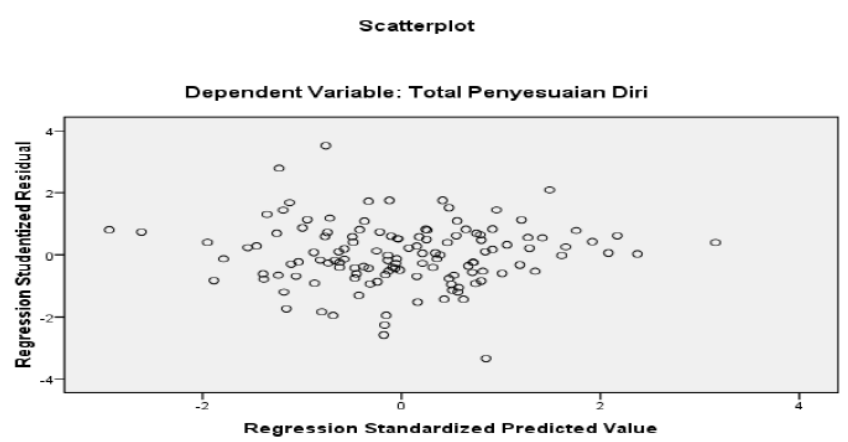

Scatterplot ( Hasil Uji Heteroskedastisitas )

Berdasarkan scatterplot di atas titik-titik menyebar dengan pola yang tidak jelas di atas dan di bawah angka 0 pada sumbu Y maka dapat disimpulkan bahwa tidak terjadi masalah heteroskedastisitas pada model regresi dalam 
penelitian ini yaitu tidak ada kesamaan varian antara variabel kecerdasan emosi dan self efficacy.

Berdasarkan hasil skor yang telah didapatkan diperoleh gambaran secara umum mengenai kondisi kecerdasan emosi, self efficacy, dan penyesuaian diri remaja awal.

Gambaran Umum Skor Variabel Kecerdasan Emosi, Self Efficacy, dan Penyesuaian Diri

\begin{tabular}{|l|l|c|c|}
\hline \multicolumn{1}{|c|}{ Variabel } & \multicolumn{1}{|c|}{ Statistik } & Hipotetik & Empirik \\
\hline \multirow{4}{*}{ Kecerdasan Emosi } & Skor Minimum & 20 & 38 \\
\cline { 2 - 4 } & Skor Maksimum & 80 & 71 \\
\cline { 2 - 4 } & Mean & 50 & 56,36 \\
\cline { 2 - 4 } & Standar Deviasi & 10 & 6,176 \\
\hline \multirow{4}{*}{ Self Efficacy } & Skor Minimum & 34 & 73 \\
\cline { 2 - 4 } & Skor Maksimum & 136 & 134 \\
\cline { 2 - 4 } & Mean & 85 & 101,72 \\
\cline { 2 - 4 } & Standar Deviasi & 17 & 10,549 \\
\hline \multirow{4}{*}{ Penyesuaian Diri } & Skor Minimum & 31 & 116 \\
\cline { 2 - 4 } & Skor Maksimum & 124 & 90,12 \\
\cline { 2 - 4 } & Mean & 77,5 & 9,656 \\
\cline { 2 - 4 } & Standar Deviasi & 15,5 & \\
\hline
\end{tabular}

Rentang Nilai dan Kategori Skor pada Variabel Kecerdasan Emosi

\begin{tabular}{|c|c|c|}
\hline Rumus Interval & Rentang Nilai & Kategori Skor \\
\hline $\mathrm{x} \leq \mu-1,5 \sigma$ & $\mathrm{x} \leq 35$ & Sangat Rendah \\
\hline$\mu-1,5 \sigma<\mathrm{x} \leq \mu-0,5 \sigma$ & $35<\mathrm{x} \leq 45$ & Rendah \\
\hline$\mu-0,5 \sigma<\mathrm{x} \leq \mu+0,5 \sigma$ & $45<\mathrm{x} \leq 55$ & Sedang \\
\hline$\mu+0,5 \sigma<\mathrm{x} \leq \mu+1,5 \sigma$ & $55<\mathrm{x} \leq 65$ & Tinggi \\
\hline$\mu+1,5 \sigma<\mathrm{x}$ & $65<\mathrm{x}$ & Sangat Tinggi \\
\hline
\end{tabular}

\begin{tabular}{|c|c|c|c|c|c|}
\hline \multicolumn{6}{|c|}{ Kondisi Empiris Kecerdasan Emosi pada Remaja Awal } \\
\hline Kategorisasi & $\begin{array}{l}\text { Sangat } \\
\text { Rendah }\end{array}$ & Rendah & Sedang & Tinggi & $\begin{array}{l}\text { Sangat } \\
\text { Tinggi }\end{array}$ \\
\hline $\begin{array}{c}\text { Frekuensi } \\
\text { Data Empirik } \\
\text { dan Distribusi } \\
\text { Subjek }\end{array}$ & $\begin{array}{c}0 \\
(0 \%)\end{array}$ & $\begin{array}{c}4 \\
(3,10 \%)\end{array}$ & $\begin{array}{c}54 \\
(41,86 \%)\end{array}$ & $\begin{array}{c}63 \\
(48,84 \%)\end{array}$ & $\begin{array}{c}8 \\
(6,20 \%)\end{array}$ \\
\hline
\end{tabular}

Berdasarkan kondisi empiris di atas diketahui bahwa mean empirik variabel kecerdasan emosi lebih besar dari mean hipotetiknya yaitu sebesar 56,36 dengan standar deviasi 6,176. Dengan kondisi tersebut menunjukkan bahwa tingkat kecerdasan emosi remaja awal pada subjek penelitian berada dalam kategori tinggi yang terletak pada rentang 55 sampai 65 .

Rentang Nilai dan Kategori Skor pada Variabel Self Efficacy

\begin{tabular}{|c|c|c|}
\hline Rumus Interval & Rentang Nilai & Kategori Skor \\
\hline $\mathrm{x} \leq \mu-1,5 \sigma$ & $\mathrm{x} \leq 59,5$ & Sangat Rendah \\
\hline$\mu-1,5 \sigma<\mathrm{x} \leq \mu-0,5 \sigma$ & $59,5<\mathrm{x} \leq 76,5$ & Rendah \\
\hline$\mu-0,5 \sigma<\mathrm{x} \leq \mu+0,5 \sigma$ & $76,5<\mathrm{x} \leq 93,5$ & Sedang \\
\hline$\mu+0,5 \sigma<\mathrm{x} \leq \mu+1,5 \sigma$ & $93,5<\mathrm{x} \leq 110,5$ & Tinggi \\
\hline$\mu+1,5 \sigma<\mathrm{x}$ & $110,5<\mathrm{x}$ & Sangat Tinggi \\
\hline
\end{tabular}

Kondisi Empiris Self Efficacy pada Remaja Awal

\begin{tabular}{|c|c|c|c|c|c|}
\hline Kategorisasi & $\begin{array}{l}\text { Sangat } \\
\text { Rendah }\end{array}$ & Rendah & Sedang & Tinggi & $\begin{array}{l}\text { Sangat } \\
\text { Tinggi }\end{array}$ \\
\hline $\begin{array}{c}\text { Data } \\
\text { Frekuensi dan } \\
\text { Distribusi } \\
\text { Subjek }\end{array}$ & $\begin{array}{c}0 \\
(0 \%)\end{array}$ & $\begin{array}{c}1 \\
(0,77 \%)\end{array}$ & $\begin{array}{c}24 \\
(18,60 \%)\end{array}$ & $\begin{array}{c}77 \\
(59,69 \%)\end{array}$ & $\begin{array}{c}27 \\
(20,93 \%)\end{array}$ \\
\hline
\end{tabular}

Berdasarkan kondisi empiris di atas diketahui bahwa mean empirik variabel self efficacy lebih besar dari mean hipotetiknya yaitu sebesar 101,72 dengan standar deviasi 10,549. Dengan kondisi tersebut menunjukkan bahwa tingkat self efficacy remaja awal pada subjek penelitian berada dalam kategori tinggi yang terletak pada rentang 93,5 sampai 110,5.
Rentang Nilai dan Kategori Skor pada Variabel Pemecahan Masalah Penyesuaian Diri

\begin{tabular}{|c|c|c|}
\hline Rumus Interval & Rentang Nilai & Kategori Skor \\
\hline $\mathrm{x} \leq \mu-1,5 \sigma$ & $\mathrm{x} \leq 54,25$ & Sangat Rendah \\
\hline$\mu-1,5 \sigma<\mathrm{x} \leq \mu-0,5 \sigma$ & $54,25<\mathrm{x} \leq 69,75$ & Rendah \\
\hline$\mu-0,5 \sigma<\mathrm{x} \leq \mu+0,5 \sigma$ & $69,75<\mathrm{x} \leq 85,25$ & Sedang \\
\hline$\mu+0,5 \sigma<\mathrm{x} \leq \mu+1,5 \sigma$ & $85,25<\mathrm{x} \leq 100,75$ & Tinggi \\
\hline$\mu+1,5 \sigma<\mathrm{x}$ & $100,75<\mathrm{x}$ & Sangat Tinggi \\
\hline
\end{tabular}

Kondisi Empiris Pemecahan Masalah Penyesuaian Diri Remaja Awal

\begin{tabular}{|c|c|c|c|c|c|}
\hline Kategorisasi & $\begin{array}{c}\text { Sangat } \\
\text { Rendah }\end{array}$ & Rendah & Sedang & Tinggi & $\begin{array}{c}\text { Sangat } \\
\text { Tinggi }\end{array}$ \\
\hline $\begin{array}{c}\text { Data } \\
\begin{array}{c}\text { Frekuensi dan } \\
\text { Distribusi } \\
\text { Subjek }\end{array}\end{array}$ & $\begin{array}{c}(0 \%) \\
(0 \%)\end{array}$ & $\begin{array}{c}41 \\
(31,78 \%)\end{array}$ & $\begin{array}{c}69 \\
(53,49 \%)\end{array}$ & $\begin{array}{c}19 \\
(14,73 \%)\end{array}$ \\
\hline \multicolumn{7}{|c|}{54,25} & & & \\
\hline
\end{tabular}

Berdasarkan kondisi empiris di atas diketahui bahwa mean empirik variabel penyesuaian diri lebih besar dari mean hipotetiknya yaitu sebesar 90,12 dengan standar deviasi 9,656. Dengan kondisi tersebut menunjukkan bahwa tingkat pemecahan masalah penyesuaian diri remaja awal pada subjek penelitian berada dalam kategori tinggi yang terletak pada rentang 85,25 sampai 100,75.

Untuk mengetahui pengaruh variabel independen secara bersama-sama yaitu variabel kecerdasan emosi dan self efficacy terhadap variabel dependen yaitu pemecahan masalah penyesuaian diri dilakukan Uji F. Untuk hasil uji $F$ dapat dilihat pada tabel di bawah ini:

Hasil Uji F ( ANOVA )

\begin{tabular}{|c|c|c|c|c|c|}
\hline Model & $\begin{array}{l}\text { Sum of } \\
\text { Squares }\end{array}$ & Df & Mean Square & $\mathrm{F}$ & Sig. \\
\hline $1 \quad$ Regression & 7121.754 & 2 & 3560.877 & 93.211 & $.000^{\mathrm{a}}$ \\
\hline Residual & 4813.502 & 126 & 38.202 & & \\
\hline Total & 11935.256 & 128 & & & \\
\hline
\end{tabular}

a. Predictors: (Constant), Total Self Efficacy, Total Kecerdasan Emosi

\begin{tabular}{|c|c|c|c|c|c|c|}
\hline \multicolumn{2}{|c|}{ Model } & $\begin{array}{l}\text { Sum of } \\
\text { Squares }\end{array}$ & Df & Mean Square & \multirow{2}{*}{$\frac{F}{93.211}$} & \multirow{2}{*}{$\frac{\text { Sig. }}{.000^{2}}$} \\
\hline 1 & Regression & 7121.754 & 2 & 3560.877 & & \\
\hline & Residual & 4813.502 & 126 & 38.202 & & \\
\hline & Total & 11935.256 & 128 & & & \\
\hline
\end{tabular}

a. Predictors: (Constant), Total Self Efficacy, Total Kecerdasan Emosi

b. Dependent Variable: Total Penyesuaian Diri

Berdasarkan tabel di atas dapat diketahui bahwa nilai signifikansi kurang dari 0,05 $(0,000<0,05)$ maka dapat dikatakan bahwa variabel kecerdasan emosi dan self efficacy secara bersama-sama berpengaruh terhadap variabel penyesuaian diri sehingga hipotesis mayor yang menyatakan ada hubungan antara kecerdasan emosi dan self efficacy dalam pemecahan masalah penyesuaian diri remaja awal dapat diterima.

Analisis R2 atau koefisien determinasi digunakan untuk mengetahui seberapa besar prosentase sumbangan pengaruh variabel kecerdasan emosi dan self efficacy secara bersama-sama terhadap variabel penyesuaian diri. 


\begin{tabular}{|l|c|c|c|c|}
\hline \multirow{2}{*}{ Model } & \multicolumn{4}{|c|}{ Nilai R $^{2}$ (Model Summary) } \\
\cline { 2 - 5 } & $\mathrm{R}$ & $\mathrm{R}$ Square & $\begin{array}{c}\text { Adjusted R } \\
\text { Square }\end{array}$ & $\begin{array}{c}\text { Std. Error of the } \\
\text { Estimate }\end{array}$ \\
\hline 1 & $.772^{\mathrm{a}}$ & .597 & .590 & 6.181 \\
\hline
\end{tabular}

a. Predictors: (Constant), Total Self Efficacy, Total Kecerdasan Emosi

b. Dependent Variable: Total Penyesuaian Diri

Berdasarkan tabel di atas diketahui bahwa koefisien determinasi $\mathrm{R}$ square sebesar 0,597. Angka tersebut mengandung pengertian bahwa dalam penelitian ini kecerdasan emosi dan self efficacy memberikan sumbangan efektif sebesar $59,70 \%$ terhadap pemecahan masalah penyesuaian diri, sedangkan sisanya sebesar 40,30 \% dipengaruhi oleh faktor lain yang tidak diteliti yaitu faktorfaktor yang dapat mempengaruhi penyesuaian diri di luar variabel kecerdasan emosi dan self efficacy misalnya kondisi fisik, kepribadian, proses belajar, lingkungan, agama dan budaya. Di samping itu juga untuk melihat besarnya kontribusi dari masing-masing variabel bebas yaitu kecerdasan emosi dan self efficacy terhadap variabel pemecahan masalah penyesuaian diri dapat dilihat melalui tabel berikut ini :

Nilai $\mathbf{R}^{2}$ dari Masing-Masing Variabel Bebas Coefficients $^{\mathrm{a}}$

\begin{tabular}{|ll|r|r|r|}
\hline \multirow{2}{*}{ Model } & \multicolumn{3}{|c|}{ Correlations } \\
\cline { 2 - 5 } & Zero-order & Partial & \multicolumn{1}{c|}{ Part } \\
\hline $1 \quad \begin{array}{l}\text { Total Kecerdasan } \\
\text { Emosi } \\
\text { Total Self Efficacy }\end{array}$ & .632 & .419 & .293 \\
& .715 & .574 & .445 \\
\hline
\end{tabular}

a. Dependent Variable: Total Penyesuaian Diri

Dari tabel di atas diketahui besarnya kontribusi dari masing-masing variabel bebas dilihat melalui kolom Partial. Untuk variabel kecerdasan emosi koefisien determinasi R2 sebesar $(0,419) 2=0,175561$, ini berarti besarnya kontribusi yang diberikan terhadap variabel penyesuaian diri adalah $17,55 \%$. Sedangkan untuk variabel self efficacy, koefisien determinasi R2 sebesar $(0,574) 2=0,329476$, ini berarti besarnya kontribusi yang diberikan terhadap variabel penyesuaian diri adalah $32,95 \%$. Selain itu pengaruh variabel bebas (kecerdasan emosi dan self efficacy) secara parsial terhadap variabel dependen (penyesuaian diri), ditunjukkan dari hasil analisis uji $\mathrm{T}$.

\section{Hasil Uji T (Coefficients )}

\begin{tabular}{|l|c|c|c|c|c|}
\hline \multirow{2}{*}{ Model } & \multicolumn{3}{|c|}{} & $\begin{array}{l}\text { Standardized } \\
\text { Coefficients }\end{array}$ & \multicolumn{2}{|c|}{} \\
\cline { 2 - 7 } & Bnstandardized Coefficients & Std. Error & Beta & T & Sig. \\
\hline $1 \quad$ (Constant) & 10.349 & 5.879 & & 1.760 & .081 \\
$\quad \begin{array}{l}\text { Total Kecerdasan } \\
\quad \text { Emosi }\end{array}$ & .544 & .105 & .348 & 5.179 & .000 \\
$\quad$ Total Self Efficacy & .483 & .061 & .528 & 7.862 & .000 \\
\hline
\end{tabular}

a. Dependent Variable: Total Penyesuaian Diri

Berdasarkan tabel di atas diketahui bahwa nilai signifikansi kecerdasan emosi dan self efficacy sebesar 0,000 lebih kecil dari $0,05(0,000<0,05)$. Sehingga dapat disimpulkan bahwa kecerdasan emosi dan self efficacy secara parsial berpengaruh terhadap pemecahan masalah penyesuaian diri. Tabel coefficients di atas juga menggambarkan regresi ganda dalam persamaan garis regresi. Dari hasil tersebut tersebut dipaparkan bahwa nilai konstanta (a) $=10,349$, nilai beta dari kecerdasan emosi sebesar 0,348 dan nilai self efficacy sebesar 0,528. Dari tabel tersebut diperoleh persamaan regresinya yaitu :

\section{$Y=10,349+0,348 X_{1}+0,528 X_{2}$}

Penjelasan dari persamaan tersebut yaitu nilai konstanta sebesar 10,349 menyatakan bahwa jika tidak ada peningkatan nilai kecerdasan emosi dan self efficacy maka nilai penyesuaian dirinya adalah 10,349 . Koefisen regresi sebesar 0,348 pada variabel kecerdasan emosi menyatakan bahwa setiap penambahan satu nilai pada variabel kecerdasan emosi maka nilai penyesuaian dirinya akan meningkat sebesar 0,348 . Sedangkan setiap penambahan satu nilai variabel self efficacy akan meningkatkan variabel penyesuaian diri sebesar 0,528. Besarnya nilai korelasi dari masing-masing variabel dependen ( bebas ) yaitu kecerdasan emosi dan self efficacy terhadap variabel pemecahan masalah penyesuaian diri dapat diketahui melalui tabel di bawah ini:

Korelasi Antar Variabel (Correlations)

\begin{tabular}{|c|c|c|c|c|}
\hline & & $\begin{array}{c}\text { Total } \\
\text { Penyesuaian } \\
\text { Diri } \\
\end{array}$ & $\begin{array}{c}\text { Total } \\
\text { Kecerdasan } \\
\text { Emosi }\end{array}$ & $\begin{array}{l}\text { Total Self } \\
\text { Efficacy }\end{array}$ \\
\hline \multirow[t]{3}{*}{ Pearson Correlation } & Total Penyesuaian Diri & 1.000 & .632 & .715 \\
\hline & Total Kecerdasan Emosi & .632 & 1.000 & .538 \\
\hline & Total Self Efficacy & .715 & .538 & 1.000 \\
\hline \multirow[t]{3}{*}{ Sig. (1-tailed) } & Total Penyesuaian Diri & . & .000 & .000 \\
\hline & Total Kecerdasan Emosi & .000 & . & .000 \\
\hline & Total Self Efficacy & .000 & .000 & . \\
\hline \multirow[t]{3}{*}{$\mathrm{N}$} & Total Penyesuaian Diri & 129 & 129 & 129 \\
\hline & Total Kecerdasan Emosi & 129 & 129 & 129 \\
\hline & Total Self Efficacy & 129 & 129 & 129 \\
\hline
\end{tabular}

Dari tabel di atas diketahui bahwa korelasi antara variabel kecerdasan emosi dengan variabel penyesuaian diri sebesar 0,632 dengan nilai signifikansi kurang dari 0,000 $(0,000 \leq 0,05)$. Sedangkan, korelasi antara variabel self efficacy dengan variabel penyesuaian diri sebesar 0,715 dengan nilai signifikansi kurang dari $0,000(0,000 \leq 0,05)$. Angka korelasi yang positif menunjukkan hubungan yang positif (Priyatno, 2012). Semakin tinggi kecerdasan emosi dan self efficacy maka pemecahan masalah penyesuaian diri juga semakin meningkat. Sehingga hipotesis minor dapat diterima, yaitu : (a) ada hubungan positif antara kecerdasan emosi dengan pemecahan masalah penyesuaian diri remaja awal, dengan nilai korelasi sebesar 0,632 dan $\operatorname{Sig}(0,000) \leq 0,05$; (b) ada hubungan positif antara self efficacy dengan pemecahan masalah penyesuaian diri remaja awal, dengan nilai korelasi sebesar 0,715 dan $\operatorname{Sig}(0,000) \leq 0,05$.

\section{PEMBAHASAN DAN KESIMPULAN}

Penelitian ini bertujuan untuk mengetahui hubungan antara kecerdasan emosi dan self efficacy dalam pemecahan 
masalah penyesuaian diri remaja awal. Berdasarkan hasil yang diperoleh dari pengujian hipotesis menunjukkan bahwa adanya hubungan antara kecerdasan emosi dan self efficacy dalam pemecahan masalah penyesuaian diri remaja awal dengan angka yang ditunjukkan oleh nilai koefisien korelasi $\mathrm{R}$ sebesar 0,772, nilai $\mathrm{F}$ sebesar 93.211, dan $\mathrm{p}=0,000(\mathrm{p} \leq$ 0,05). Nilai koefisien korelasi sebesar 0,772 menunjukkan bahwa ada hubungan yang kuat antara kecerdasan emosi dan self efficacy dalam pemecahan masalah penyesuaian diri remaja awal. Sedangkan nilai $F=93,211$ dan $p=0,000$ menunjukkan bahwa persamaan regresi dapat digunakan untuk memprediksi hubungan variabel kecerdasan emosi dan self efficacy terhadap variabel pemecahan masalah penyesuaian diri. Sehingga berdasarkan hasil yang diperoleh ini hipotesis mayor dapat diterima.

Di samping itu, penelitian ini menguji hipotesis minor yaitu apakah ada hubungan positif antara kecerdasan emosi dengan pemecahan masalah penyesuaian diri remaja awal dan juga apakah ada hubungan positif antara self efficacy dengan pemecahan masalah penyesuaian diri remaja awal. Berdasarkan hasil yang diperoleh kedua hipotesis tersebut terbukti. Nilai korelasi sebesar 0,632 dengan Sig $(0,000) \leq$ 0,05 untuk hubungan antara kecerdasan emosi dengan penyesuaian diri serta nilai korelasi sebesar 0,715 dengan Sig $(0,000) \leq 0,05$ untuk hubungan antara self efficacy dengan penyesuaian diri. Nilai korelasi yang positif tersebut menunjukkan arah hubungan kedua variabel yang positif yaitu semakin tinggi kecerdasan emosi maka semakin tinggi pula penyesuaian diri remaja awal, dan sebaliknya semakin rendah kecerdasan emosi maka semakin rendah pula penyesuaian diri remaja. Begitu pula pada variabel self efficacy, semakin tinggi self efficacy maka semakin tinggi pula penyesuaian diri remaja awal, dan sebaliknya semakin rendah self efficacy maka semakin rendah pula penyesuaian diri remaja.

Hasil penelitian juga menunjukkan bahwa sumbangan efektif yang diberikan oleh variabel kecerdasan emosi dan self efficacy sebesar $59,70 \%$ terhadap pemecahan masalah penyesuaian diri remaja awal sedangkan sisanya sebesar 40,30\% dipengaruhi oleh faktor-faktor lain yang mempengaruhi penyesuaian diri di luar variabel kecerdasan emosi dan self efficacy misalnya kondisi fisik, kepribadian, proses belajar, lingkungan, agama dan budaya. Selain itu dari masing-masing variabel bebas yaitu kecerdasan emosi dan self efficacy juga dapat dilihat kontribusinya terhadap variabel penyesuaian diri. Untuk variabel kecerdasan emosi memberikan kontribusinya terhadap variabel penyesuaian diri sebesar $17,55 \%$. Sedangkan untuk variabel self efficacy besarnya kontribusi yang diberikan terhadap variabel penyesuaian diri adalah sebesar 32,95\%.

Remaja kerapkali menghadapi permasalahan seiring dengan perubahan yang terjadi pada fisik, kognitif, dan sosioemosionalnya. Dalam menghadapi masalah-masalah tersebut mereka berupaya mencari pemecahan atau jalan keluarnya sehingga mampu untuk menyesuaikan diri dengan keadaan yang terjadi. Penyesuaian diri menurut Atwater (1983) terdiri dari perubahan dalam diri dan lingkungan sekitar untuk mencapai suatu hubungan yang memuaskan dengan orang lain dan lingkungan sekitar. Hasil penelitian menunjukkan, tingkat pemecahan masalah penyesuaian diri subjek penelitian ini tergolong tinggi yang ditunjukkan dengan mean empirik yang lebih besar dari mean hipotetik yaitu sebesar 90,12 dengan standar deviasi 9,656. Berdasarkan hal tersebut, aspek-aspek penyesuaian diri yaitu persepsi terhadap realitas, kemampuan mengatasi stres dan kecemasan, gambaran diri yang positif, kemampuan mengekspresikan emosi dengan baik, dan hubungan interpersonal yang baik, sebagian besar telah dimiliki oleh subjek pada penelitian ini yaitu sebanyak 69 orang atau 53,49\% dari 129 subjek penelitian. Dengan hasil tersebut terlihat bahwa tingkat penyesuaian diri yang dialami oleh remaja awal berbeda-beda. Perbedaan tingkatan penyesuaian diri yang dialami oleh remaja awal dapat dipengaruhi oleh beberapa faktor yaitu faktor kondisi fisik, kepribadian, proses belajar, lingkungan, agama serta budaya.

Menurut Schneiders (dalam Ali \& Asrori, 2011), kondisi fisik mempengaruhi proses penyesuaian diri remaja yang digambarkan melalui keberadaan sistem utama tubuh misalnya sistem saraf dan kesehatan fisik yang dimiliki individu. Fungsi sistem saraf yang memadai diperlukan bagi penyesuaian diri yang baik, akan tetapi bila penyimpangan terjadi dalam sistem saraf akan berpengaruh pada kondisi mental dan penyesuaian diri. Hal tersebut dapat dicontohkan melalui gejala psikosomatis, pada gejala tersebut terjadi keberfungsian sistem saraf yang kurang baik sehingga mempengaruhi penyesuaian diri yang kurang baik. Di samping itu, penyesuaian diri individu akan lebih mudah dilakukan bila kondisi fisiknya yang sehat karena dengan fisik yang sehat dapat menimbulkan penerimaan diri, percaya diri, dan harga diri. Faktor kepribadian memberikan pengaruh terhadap penyesuaian diri remaja. Dalam hal ini remaja yang memiliki kemauan, kemampuan, dan belajar secara bersungguhsungguh untuk merubah diri dalam merespon lingkungan sekitarnya, tidak akan mengalami kesulitan dalam menyesuaikan diri dibandingkan dengan remaja yang tidak memiliki kemauan untuk berubah. Kemampuan dalam mengatur diri dan inteligensi juga mempengaruhi penyesuaian diri remaja.

Kemampuan mengatur diri muncul dari kualitas inteligensi yang memiliki peranan penting dalam penyesuaian diri. Inteligensi sangat penting bagi perkembangan gagasan, prinsip, dan tujuan berperan dalam proses penyesuaian diri misalnya dalam melakukan pemilihan dan mengambil keputusan penyesuaian diri. Faktor pendidikan remaja yang meliputi proses belajar, pengalaman, latihan, dan determinasi diri mempengaruhi tingkatan penyesuaian diri remaja. Dalam 
proses belajar remaja mengalami hal-hal seperti melatih keterampilan atau kebiasaan, mencoba-coba dan mengalami kegagalan terhadap kegiatan-kegiatan yang dilakukan dalam proses penyesuaian diri. Tentu saja hal ini berkaitan erat dengan determinasi diri yaitu remaja harus mampu dalam menentukan dirinya sendiri untuk melakukan proses penyesuaian diri. Pengaruh lingkungan seperti lingkungan keluarga, sekolah, dan masyarakat memberikan peran penting bagi remaja. Penerimaan diri dalam keluarga, sosialisasi di sekolah, dan nilai-nilai yang berlaku di masyarakat mempengaruhi penyesuaian diri pada remaja.

Goleman (2009) mengatakan bahwa emosi merujuk pada suatu perasaan dan pikiran-pikiran yang khas, suatu keadaan biologis dan psikologis, dan serangkaian kecenderungan untuk bertindak. Pandangan mengenai emosi tersebut mengarahkan pada bagaimana emosi dapat memberikan pengaruh bagi remaja dalam bertindak untuk menyesuaikan diri dengan lingkungan sekitar. Berdasarkan hasil uji variabel kecerdasan emosi dengan pemecahan masalah penyesuaian diri didapatkan bahwa adanya hubungan positif antara kecerdasan emosi dengan pemecahan masalah penyesuaian diri remaja awal yang mana hubungan ini signifikan yaitu sig $(0,000) \leq 0,05$ dengan nilai korelasi sebesar 0,632. Dengan besar nilai korelasi tersebut menunjukkan adanya hubungan yang kuat antara kecerdasan emosi dengan penyesuaian diri. Menurut Salovey dan Mayer (1990), kecerdasan emosi merupakan bagian dari kecerdasan sosial yang melibatkan kemampuan untuk memantau emosi dan perasaan diri sendiri dan orang lain, membedakan emosi diri sendiri dan orang lain, serta menggunakan informasi tersebut untuk mengarahkan pikiran dan tindakan seseorang.

Tingkat kecerdasan emosi dari subjek penelitian tergolong tinggi yang ditunjukkan dengan mean empirik yang lebih besar dari mean hipotetik yaitu sebesar 56,36 dengan standar deviasi 6,176. Hal ini menunjukkan bahwa aspekaspek kecerdasan emosi yaitu mengenali emosi diri, mengelola emosi, memotivasi diri, mengenali emosi orang lain, dan membina hubungan dengan orang lain, sebagian besar telah dimiliki oleh subjek pada penelitian ini yaitu sebanyak 63 orang atau 48,84\% dari 129 subjek penelitian. Subjek penelitian lainnya yang tidak tergolong dalam kategori tinggi tersebar dalam kategori rendah, sedang, dan sangat tinggi. Perbedaan tingkatan kecerdasan emosi pada remaja awal ini dapat disebabkan oleh faktor-faktor yang mempengaruhi kecerdasan emosi itu sendiri yaitu faktor yang bersifat bawaan genetik dan faktor dari lingkungan. Menurut Goleman (2009), faktor bawaan genetik dapat dilihat melalui perbedaan temperamen seperti penakut, pemberani, periang, dan pemurung yang dibawa oleh individu sejak lahir. Perbedaan temperamen ini disebabkan oleh perbedaan bawaan dalam jaringan sirkuit saraf dalam otak yang mempengaruhi emosi. Pada setiap emosi yang dialami oleh individu memiliki perbedaan dalam seberapa mudah emosi dipicu, lama berlangsungnya emosi tersebut, dan seberapa sering emosi tersebut terjadi. Anak yang penakut sejak kecil akan memiliki sirkuit saraf yang lebih reaktif terhadap hal-hal yang dapat menimbulkan stress, rasa takut, cemas ataupun rasa bersalah dibandingkan anak yang pemberani. Hal ini akan meninggalkan bekas-bekas ingatan dalam amigdala yang kemudian ingatan tersebut terbawa hingga beranjak dewasa. Bekas-bekas ingatan tersebut menjadi pengalaman emosi dan kemampuan dalam mengembangkan emosi yang berbeda-beda bagi setiap individu.

Selain itu, Goleman (2009) juga menjelaskan bagaimana kecerdasan emosi tersebut dipengaruhi oleh lingkungan. Pembelajaran emosi dimulai sejak awal kehidupan yang berlanjut sepanjang masa-masa kehidupan manusia yang semuanya berawal dari lingkungan keluarga. Dalam keluarga, hal-hal yang diucapkan dan dilakukan oleh orang tua secara langsung pada anak-anaknya, contoh-contoh yang diberikan oleh orang tua sewaktu menangani perasaan mereka sendiri menjadi pembelajaran dan perkembangan emosi anak. Orang tua yang terampil secara emosional dapat membantu anak dengan memberi dasar keterampilan emosional seperti belajar bagaimana mengenali, mengelola, dan memanfaatkan perasaan-perasaan; berempati; dan menangani perasaan-perasaan yang muncul dalam hubunganhubungan mereka. Anak yang terampil secara emosional mampu menunjukkan banyak kasih sayang pada orang tua, lebih mampu menangani emosi seperti ketika marah, mudah bergaul, dan tidak memiliki masalah tingkah laku seperti agresif dibandingkan dengan anak yang kurang mendapat pembelajaran emosi secara terampil. Kecerdasan emosi sebagai sebuah cermin untuk merefleksikan kemampuan seseorang dalam bernegosiasi dengan baik terhadap orang lain dan untuk mengontrol diri selain itu juga kecerdasan emosi sebagai kemampuan untuk mengatasi tantangan di lingkungan sehari-hari dan membantu memprediksi kesuksesan dalam hidup termasuk dalam masalah pribadi dan karir (Yusof \& Yaacob, 2012). Di samping itu, hubungan kecerdasan emosi dengan penyesuaian diri terlihat pada pelajar yang sedang mengalami masa transisi dari primary school menuju secondary school (Adeyemo, 2005).

Seperti yang telah dijelaskan sebelumnya, selain perubahan fisik dan sosio-emosional remaja juga mengalami perubahan kognitif. Perubahan kognitif ini tidak terlepas dari lingkungan sekitar atau lingkungan sosial remaja. Teori Sosial-Kognitif dari Bandura (dalam Schunk\& Meece, 2005) menyebutkan bahwa keberfungsian manusia merupakan hasil dari interaksi di antara faktor personal (kognisi, emosi), perilaku dan kondisi lingkungan. Dari pandangan ini self efficacy mempengaruhi perilaku seseorang dan lingkungan dimana individu tersebut berinteraksi dan juga dipengaruhi oleh tindakan seseorang dan kondisi di lingkungan tersebut. 
Berdasarkan hasil uji variabel self efficacy dengan pemecahan masalah penyesuaian diri didapatkan bahwa adanya hubungan positif antara kecerdasan emosi dengan pemecahan masalah penyesuaian diri remaja awal yang mana hubungan ini signifikan yaitu sig $(0,000) \leq 0,05$ dengan nilai korelasi sebesar 0,715. Dengan besar nilai korelasi tersebut menunjukkan adanya hubungan yang kuat antara self efficacy dengan penyesuaian diri.

Berdasarkan hasil penelitian didapatkan bahwa tingkat self efficacy dari subjek penelitian tergolong tinggi yang ditunjukkan dengan mean empirik yang lebih besar dari mean hipotetik yaitu sebesar 101,72 dengan standar deviasi 10,549. Hal ini menunjukkan bahwa aspek-aspek self efficacy yaitu tingkat (level), keadaan umum (generality), dan kekuatan (strength), sebagian besar telah dimiliki oleh subjek pada penelitian ini yaitu sebanyak 77 orang atau 59,69\% dari 129 subjek penelitian. Subjek penelitian lainnya yang tidak tergolong dalam kategori tinggi tersebar dalam kategori rendah, sedang, dan sangat tinggi. Perbedaan tingkatan self efficacy pada remaja awal ini dapat disebabkan oleh faktorfaktor self efficacy lainnya seperti budaya, gender, sifat dari tugas yang dihadapi, insentif eksternal, status individu dalam lingkungan, dan informasi tentang kemampuan dirinya.

Budaya memberikan pengaruh terhadap self efficacy melalui nilai, kepercayaan, dan proses pengaturan diri yang berfungsi sebagai sumber penilaian self efficacy. Oettingen (1995) mengatakan bahwa budaya mempengaruhi self efficacy melalui sistem nilai yang berbeda-beda pada keluarga, sekolah, tempat kerja ataupun komunitas. Sistem nilai yang berbeda-beda tersebut mempengaruhi peningkatan self efficacy individu. Perbedaan gender berpengaruh terhadap self efficacy. Selain faktor budaya, perbedaan gender juga dapat mempengaruhi self efficacy. Hasil penelitian dari Mikolyski (2008) menunjukkan bahwa self efficacy terhadap tugas-tugas karir pada remaja perempuan lebih tinggi daripada remaja laki-laki dan remaja perempuan menunjukkan variasi tugas karir yang lebih besar (dalam pekerjaan seni, layanan pelanggan, mengajar, perawat, koordinator acara, desain pakaian, asisten administrasi) dari remaja laki-laki yang lebih cenderung ke arah pekerjaan mekanik, komputer, atletik, dan olahraga. Kompleksitas kesulitan tugas yang dihadapi oleh individu juga memberikan pengaruhnya terhadap self efficacy individu. Semakin sulit tugas yang dihadapi maka semakin rendah individu menilai kemampuannya. Sebaliknya dengan tugas yang mudah dan sederhana maka semakin tinggi individu menilai kemampuannya.

Faktor lain yang dapat mempengaruhi self efficacy individu adalah insentif yang diperolehnya. Bandura menyatakan bahwa salah satu faktor yang dapat meningkatkan self efficacy adalah competent contingens incentive, yaitu insentif yang diberikan oleh orang lain yang merefleksikan keberhasilan seseorang. Hal ini dapat ditunjukkan dari penelitian Schunk (1983), yang memberikan reward kepada subjek penelitian atas tugas-tugas yang dilakukan. Penelitian ini menerapkan konsep self efficacy dari Bandura, yang menyatakan penguatan muncul akibat karena informasi dan dorongan yang diperoleh dan juga untuk mengubah perilaku individu dapat dilakukan dengan memperkuat pemahaman terhadap self efficacy. Pemahaman tersebut mempengaruhi pilihan aktivitas, usaha yang dikembangkan, kegigihan dalam mengahadapi kesulitan. Hasil penelitian menunjukkan bahwa dengan memberikan reward lebih meningkatkan self efficacy daripada tidak diberikan reward, khususnya ketika anak-anak dilibatkan dalam pencapaian yang sebenarnya. Individu yang memiliki status yang lebih tinggi akan memperoleh derajat kontrol yang lebih besar sehingga self efficacy yang dimilikinya juga tinggi. Sedangkan individu yang memiliki status yang lebih rendah akan memiliki kontrol yang lebih kecil sehingga self efficacy yang dimilikinya juga rendah. Individu akan memiliki self efficacy tinggi, jika memperoleh informasi positif mengenai dirinya, sementara individu akan memiliki self efficacy rendah, jika memperoleh informasi negatif mengenai dirinya. Perolehan informasi ini dapat diperoleh melalui persuasi sosial. Individu yang dipersuasi secara verbal bahwa dirinya mampu dalam melakukan tugas akan menumbuhkan keyakinan dan usaha yang besar daripada individu yang diragukan dan ditunjukkan kekurangankekurangan pada dirinya (Bandura, 1994).

Dari hasil penelitian yang diperoleh maka disimpulkan bahwa ada hubungan yang kuat antara kecerdasan emosi dan self efficacy dalam pemecahan masalah penyesuaian diri remaja awal, ada hubungan positif yang kuat antara kecerdasan emosi dengan pemecahan masalah penyesuaian diri remaja awal, ada hubungan positif yang kuat antara self efficacy dengan pemecahan masalah penyesuaian diri remaja awal, dan sumbangan efektif yang diberikan oleh variabel kecerdasan emosi dan self efficacy sebesar 59,70\% terhadap pemecahan masalah penyesuaian diri remaja awal sedangkan sisanya sebesar $40,30 \%$ dipengaruhi oleh faktorfaktor lain yang dapat mempengaruhi penyesuaian diri di luar variabel kecerdasan emosi dan self efficacy misalnya kondisi fisik, kepribadian, proses belajar, lingkungan, agama dan budaya. Selain itu, besarnya kontribusi yang diberikan terhadap variabel penyesuaian diri dari masing-masing variabel bebas adalah $17,55 \%$ dari variabel kecerdasan emosi dan $32,95 \%$ dari variabel self efficacy.

Berdasarkan hasil penelitian tersebut dapat diajukan berbagai saran yaitu: a) bagi remaja awal yang memiliki kecerdasan emosi, self efficacy dan penyesuaian diri yang tinggi diharapkan mampu mempertahankan dan membagikan pengalaman-pengalamannya terhadap remaja lain seperti dalam membangun dan memahami emosi dalam diri, memunculkan keyakinan dalam diri serta kemampuan dalam menyesuaikan diri; b) bagi orang tua, diharapkan dapat terus 
memantau perkembangan emosi anak, memberikan penguatan dan keyakinan terhadap kemampuan yang dimiliki oleh anak mereka terutama ketika beranjak remaja agar mereka mampu dalam mengenali emosi dalam diri dan orang lain, mengekspresikan emosi dengan baik, menjalin komunikasi yang baik dengan orang lain, sehingga mereka dapat menyesuaikan diri dan menerima kondisi yang terjadi lingkungan di sekitar mereka dengan baik; c) bagi peneliti selanjutnya, diharapkan dapat meninjau kembali mengenai metode-metode yang digunakan dalam penelitian ini seperti menentukan jumlah sampel yang digunakan dalam uji coba alat ukur penelitian, menentukan metode untuk pengambilan sampel penelitian dan juga meninjau kembali alat ukur yang dipakai terkait dengan banyaknya item-item yang gugur pada skala pengukuran serta dapat meneliti lebih dalam lagi mengenai faktor-faktor yang mempengaruhi pemecahan masalah penyesuaian diri remaja awal selain kecerdasan emosi dan self efficacy. Dengan demikian, penjelasan-penjelasan terhadap hasil penelitian ini menjadi lebih komprehensif dan menjadi suatu karya yang bermanfaat dalam memberikan kontribusi terhadap perkembangan ilmu psikologi di Indonesia khususnya psikologi yang berkaitan dengan kehidupan remaja.

\section{DAFTAR PUSTAKA}

Adeyemo, D. A. (n.d.). The Buffering Effect of Emotional Intelligence on The Adjustment of Secondary School Students in Transition. Electronic Journal of Research in Educational Psychology.

Agung, G \& Budiani, M. S. (2013). Hubungan Kecerdasan Emosi dan Self Efficacy dengan Tingkat Stress Mahasiswa yang Sedang Mengerjakan Skripsi. Character, Volume 01 Nomor 02 Tahun 2013.

Ali, M., \& Asrori, M. (2011). Psikologi Remaja. Jakarta: PT.Bumi Aksara.

Anonim. (2012, Juli 24). Penyebab Utama Remaja Bunuh Diri karena Cinta. Suara Karya Online . Diakses pada tanggal 10 Oktober 2012 dari http://www.suarakaryaonline.com/news.html?id=307949

Anwar, A.I.D. (2009). Hubungan Self Efficacy dengan Kecemasan Berbicara di Depan Umum Pada Mahasiswa Fakultas Psikologi Universitas Sumatera Utara. Skripsi, 1-81.

Ariefyanto, M.I. (2012, Mei 23). Mengatasi Kenakalan Remaja. Diakses pada tanggal 10 Oktober 2012 dari Republika Online . http://www.republika.co.id/berita/rol-to-school/tim-jurnalistiksma-se-jakarta-timur/12/05/23/m4gut0-mengatasi-kenakalanremaja

Atwater, E. (1983). Psychology of Adjustment (Second Edition). USA: Prentice- Hall.

Azwar, S. (2012). Penyusunan Skala Psikologi. Yogyakarta: Pustaka Belajar.

(2010). Reliabilitas dan Validitas. Yogyakarta: Pustaka Belajar.

Bandura, A. (1994). Self - Efficacy. Encyclopedia of human behavior (Vol. 4, pp. 71-81). Azwar, S. (2010). Penyusunan skala psikologi. Yogyakarta: Pustaka Pelajar.
(1977) . Self-efficacy: Toward a Unifying Theory of Behavioral Change. Psychological Review 1977, Vol. 84, No. 2, 191-215.

(1999) . Social Cognitive Theory: An Agentic Perspective. Asian Journal of Social Psychology (1999) 2: 21 41.

Bar-on, R. (2006). The Bar-On Model of Emotional-Social Intelligence (ESI). Psicothema 2006. Vol. 18, supl., pp. 13-25.

Boediono \& Koster, W. (2001). Teori dan Aplikasi Statistika dan Probabilitas. Bandung: PT Remaja Rosdakarya.

Eliasa, E. I. (2011). Kenakalan Remaja Pada Anak SMP. Diakses Mei 2012, dari http://staff.uny.ac.id/sites/default/files/tmp/Microsoft\%20Word $\% 20-$ \%20Kenakalan\%20Remaja\%20 SMP\%206\%20Klaten .pdf

Feist, J. \& Feist, G.J. (2009). Theories of Personality, Seventh Edition. America, New York: McGraw-Hill.

Goleman, D. (2009). Kecerdasan Emosional : Mengapa EI lebih penting daripada IQ. Terjemahan: Hermaya, T. Jakarta: Gramedia Pustaka Utama.

Hastuti, D. (2010, Maret 14). Awas Tren Ponsel Pacu Perilaku Konsumtif. harianjoglosemar.com. Diakses pada tanggal 11 Februari 2013 dari http://www.edisicetak.joglosemar.co/berita/awas-tren-ponselpacu-perilaku-konsumtif-11482.html.

Hein, S. (1996). EQ For Everybody. Clearwater Florida: Aristotle Press.

Higgins, J.E. \& Kleinbaum, A.P. (1985). International to Randomized Clinical Trials with an Emphasis on Contraceptive Research. Family Health International.25-30.

Hurlock, E.B. (1991). Adolescent Development. New York: Mc.Graw-Hill

(1994). Psikologi Perkembangan Suatu Pendekatan Rentang Kehidupan. Jakarta: Erlangga

Kartono, K. (2000). Hygine Mental. Bandung: Mandar Maju.

Keputusan Menteri Kesehatan Republik Indonesia Nomor 265/Menkes/SK/II/2010. Pedoman Komunikasi Otak Untuk Meningkatkan Kesehatan Intelegensia Pada Remaja.

Kertamuda, F. \& Herdiansyah, H. (April 2009). Pengaruh Strategi Coping terhadap Penyesuaian Diri Mahasiswa Baru. Jurnal Universitas Paramadina Vol.6 No.1.

Kusdiyati, S. \& Halimah, L. (2011). Penyesuaian Diri di Lingkungan Sekolah pada Siswa Kelas XI SMA Pasundan 2 Bandung. Humanitas, Vol. VIII No.2 Agustus 2011.

Martin, A. D. (2011). Emotional Quality Management:Refleksi,Revisi dan Revitalisasi Hidup Melalui Kekuatan Emosi. Jakarta: HR Excellency.

Maryati, I. (2008). Hubungan Antara Kecerdasan Emosi dan Keyakinan Diri (SELF-EFFICACY) dengan Kreativitas Pada Siswa Akselerasi. Skripsi, 1-132.

Mikolyski, D. (2008). Self-Efficacy, Identity, Career Knowledge, and Interests in Adolescents. Thesis, 1-77.

Monks, F. J., Knoers, A. M., \& Haditono, S. R. (2006). Psikologi Perkembangan. Yogyakarta: Gadjah Mada University Press. 
Mukhid, A. (2009). SELF-EFFICACY (Perspektif Teori Kognitif Sosial dan Implikasinya terhadap Pendidikan). Tadris, Volume 4.Nomor 1 .

Nasution, S. (2011). Metode Research (Penelitian Ilmiah). Jakarta: PT.Bumi Aksara.

Nurdin. (2009). Pengaruh Kecerdasan Emosional terhadap Penyesuaian Sosial Siswa di Sekolah. Jurnal Administrasi Pendidikan Vol.IX No.1 April 2009.

Nurita, M. (2012). Hubungan Antara Kecerdasan Emosional (EQ) dengan Kinerja Perawat pada. Jurnal Psikologi .

Oettingen, G. (1995). Cross-Cultural Perspective on Self Efficacy, dalam A. Bandura (Ed), Self efficacy in changing societies (pp.149-176). New York: Cambridge University Press

Patriana, P. (2007). Hubungan Antara Kemandirian dengan Motivasi Bekerja Sebagai Pengajar Les Privat Pada Mahasiswa di Semarang. Skripsi, 1-94 .

Peilouw, F. J \& Nursalim, M. (2013). Hubungan antara Pengambilan Keputusan dengan Kematangan Emosi dan Self -Efficacy pada Remaja. Character, Volume 01 Nomor 02 Tahun 2013.

Priyatno, D. (2012). Belajar Praktis Analisis Parametrik dan Non Parametrik dengan SPSS. Yogyakarta: Gava Media.

Riduwan \& Sunarto, H. (2009). Pengantar Statistika untuk Penelitian:Pendidikan Sosial,Komunikasi, Ekonomi, dan Bisnis. Bandung: Alfabeta.

Runyon, R.P. \& Haber, A. (1984). Psychology of Adjustment. Illinois : The Dorsey Press

Salovey, P. \& Mayer, J. D. (1990). Emotional intelligence. Imagination, Cognition, and Personality, 9, 185-211.

Santrock, J. W. (2007). Remaja, Edisi 11. Erlangga.

Saputra, V. A \& Satiningsih. (n.d.). Pengaruh Internal Locus of Control dan Kecerdasan Emosi terhadap Kemampuan Pemecahan Masalah pada Mahasiswa Fakultas Ilmu Pendidikan Universitas Negeri Surabaya.

Sarwono, S. W. (2011). Psikologi Remaja. Jakarta: Rajawali Pers.

Schunk, D. H. (1983). Reward Contingencies and the Development of Children's Skills and Self-Efficacy. Journal of Educational Psychology, 75, 511-518.

Schunk, D.H. \& Meece, J.L. (2005). Self-Efficacy Development In Adolscences, 71-96.

Setiawan, N. (2005, Mei). "TEKNIK SAMPLING”. Diakses pada April 2012, dari http://muntohar.files.wordpress.com/2009/10/teknik_sampling1. pdf

Stenberg, R. J. (2009). Cognitive Psychology : Fifth Edition. USA: Wadsworth.

Sugiyono. (2012). Statistika Untuk Penelitian. Bandung: Alfabeta.

Sundari, S. (2005). Kesehatan Mental. Jakarta. PT. Rineka Cipta.

Suryabrata, S. (2000). Metodologi Penelitian. Jakarta: PT Raja Grafindo Persada.

Suseno, D. (2012, September 25). Ketika Bunuh Diri Jadi Solusi. Pontianak Post . Diakses pada tanggal 10 Oktober 2012 dari http://www.pontianakpost.com/index.php?mib=berita.detail\&id $=116338$

Syafiq, M. (2010). Hubungan Tipe Kepribadian dengan Penyesuaian Diri Siswa di Madrasah Tsanawiyah Khadijah Malang. Skripsi, $1-173$.
Yusof, N.M. \& Yaacob, N.R.N. (2012). Emotional Intelligence and Attitude of Students from Public Institutes of Higher Learning. Science Journal of Psychology.

Yusuf, S. (2011). Psikologi Perkembangan Anak \& Remaja. Bandung: PT. Remaja Rosdakarya. 